Review

\title{
Hydrometeorological Research in South Africa: A Review
}

\section{Christina M. Botai ${ }^{1, *}$, Joel O. Botai ${ }^{2, \dagger}$, Shepherd Muchuru ${ }^{2, \dagger}$ and Isaac Ngwana ${ }^{1, \dagger}$}

1 South African Weather Service, Private Bag X097, Pretoria 0001, South Africa; E-Mail: isaac.ngwana@weathersa.co.za

2 Department of Geography, Geoinformatics and Meteorology, University of Pretoria, Pretoria 0001, South Africa; E-Mails: joel.botai@up.ac.za (J.O.B.); shephido@yahoo.com (S.M.)

$\dagger$ These authors contributed equally to this work.

* Author to whom correspondence should be addressed; E-Mail: christina.botai@weathersa.co.za; Tel.: +27-12-367-6269; Fax: +27-12-367-6189.

Academic Editor: Athanasios Loukas

Received: 12 December 2014 / Accepted: 19 March 2015 / Published: 15 April 2015

\begin{abstract}
Water resources, particularly in arid and semi-arid regions of the world are of great concern, as they are closely linked to the wellbeing of humankind. Sophisticated hydrological prediction tools are required to assess climatic and hydrometeorological conditions, as they impact the sustainability of water resources as well as water availability. Research and data collection activities from multi-hydrometeorological sensors (e.g., gauges, radars, satellites) form the basis for quantifying the impact of extreme episodes along the hydrologic phases that manifest in terms of the magnitude, duration and frequency of floods, droughts and other hydrometeorological hazards that affect water resources management. A number of hydrometeorological research activities have been reported in the literature by various researchers and research groups globally. This contribution presents (a) a review of the hydrometeorology resource landscape in South Africa; (b) an analysis of the hydrometeorology services and products in South Africa; (c) a review of the hydrometeorological research that has been conducted in South Africa for the last four decades; and (d) highlights on some of the challenges facing the sustained advancement of research in hydrometeorology in South Africa.
\end{abstract}

Keywords: hydrometeorology; water resources; extreme events; South Africa weather service 


\section{Introduction}

Hydrometeorology is an interdisciplinary field of research that combines knowledge from the atmospheric sciences and hydrology to study the transfer and exchange of water and energy between land and the lower atmosphere. This field of research can be seen to exist at the interface of two well-developed disciplines, meteorology and hydrology. In general, hydrometeorology provides ever-advancing knowledge about the hydrological cycle, which is an integral part of the wellbeing of humankind on Earth [1]. The scope of hydrometeorology research is clearly interdisciplinary and includes analysis of the space-time properties of proxy parameters such as precipitation, maximum precipitation amount, minimum and maximum temperatures and their influence on river systems and dams. In this regard, this field of research is concerned with a broad understanding of the complex interactions between weather and the water resources of the earth [1]. It is worth mentioning that water is one of the most common substances on the surface of the earth, with a total volume of $\sim 1,386,984 \times 10^{3} \mathrm{~km}^{3}$ in various storage locations or reservoirs, as depicted in Figure 1 .

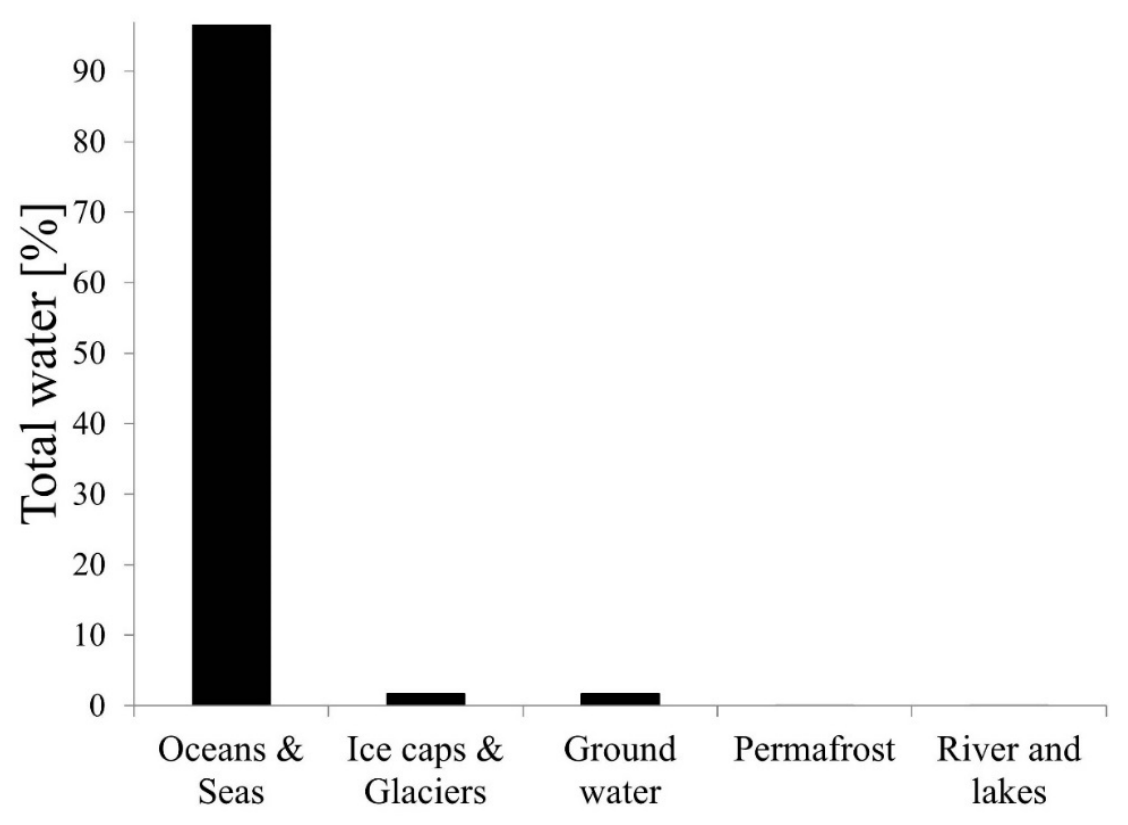

Figure 1. Percentage composition of total water in various reservoirs.

Water is cycled between each of the reservoirs through the hydrologic cycle - the movement of water among ocean, biosphere and atmosphere. The theory behind hydrological processes has been documented by various researchers; for example, see articles by [2-6]. The flow chart in Figure 2 depicts a simplified process of water transfer between the land, oceans and the atmosphere. The actual hydrological process is, however, very complex and requires an in-depth understanding of how each process interacts with the others, energy transformation between the different water phases (e.g., solid, liquid and gas), movement and distribution of water on Earth and consequently their effects on water resources [7]. 


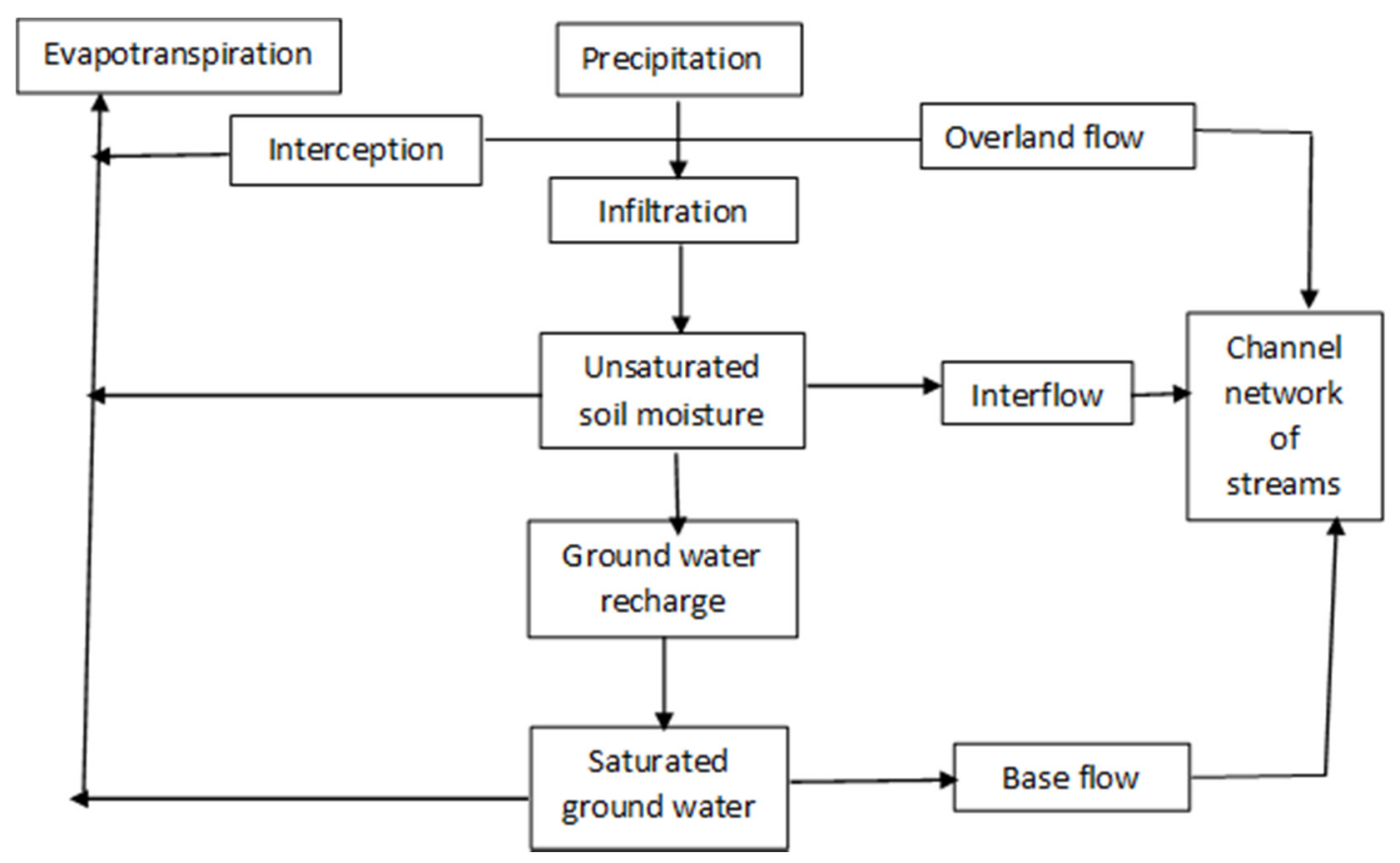

Figure 2. Schematic representation of hydrologic cycle. Adapted from [2].

Hydro-met extreme events such as storm rainfall, floods, drought, avalanches, hails, etc., have the potential to cause economic damage, social disruption and even loss of human life worldwide [8]. Such extreme events are of great concern as they have severe impacts on socio-economic development e.g., causing significant damage to agriculture, ecology and infrastructure as well as disruption of human activities, injuries and loss of life [9]. Increases in the magnitude and frequency of high rainfall events may lead to an increase in frequency of flood events, landslides, soil erosion, accumulation of silt in dams, inundation of lowland areas and aquifer recharge due to rising water tables [10]. According to the reports presented by the Intergovernmental Panel on Climate Change [11], there is clear evidence that the number of weather and climate extremes, warm spells or heat waves and heavy precipitation has increased globally since 1950, though large regional differences also exist. Changes in some of the extreme events have been linked to anthropogenic climate change drivers. These anthropogenic manifestations are often in the form of global warming of extreme daily minimum and maximum temperatures at a global scale [11]. All these factors pose a serious concern to various communities, globally and at the regional level. For instance, the possible collapse of small dams and reservoirs due to extreme precipitation is likely to increase (in the future), putting the lives of hundreds of thousands of people in South Africa already settled on floodplains in danger [12]. Furthermore, global warming produced by anthropogenic emissions of greenhouse gases is likely to impact the water cycle at scales ranging from global [13] to local [14].

Extreme weather and climate events have received increased attention recently due to increasing costs associated with their occurrence [15]. In particular, various studies have focused on variability and trends in extreme weather and climate events with the aim of understanding the observed trends. For example, using daily rainfall records at 125 stations, [10] analyzed trends in heavy rainfall, total rainfall and number of dry days in Australia, for the period of 1910-1990. The authors reported increasing trends in heavy rainfall and total rainfall during both the summer half-year and winter half-year across the country except in the far southwest Western Australia and inland Queensland. 
A reduction in the number of dry days in both halves of the year was also observed across the country except in the far southwest part of the country and at a few stations in eastern Australia. In [16], Osborn et al., analyzed daily precipitation data from 110 United Kingdom (UK) stations over the period 1961-1995 to assess intensity distribution of the precipitation amounts in the UK. The authors observed a decline in daily intensity of precipitation in light and medium events as well as an increase in the heaviest events during winter. The observed change was reported to be fairly uniform across the country and apparent even when older data are analyzed dating back to 1931 or 1908 . The reserve was observed in summer, indicating a decline in the proportion of the seasonal total in the heaviest events.

In [17], Brunetti et al., analyzed 45 daily precipitation records covering over 120 years (1880-2002) in Italy to investigate changes in the daily precipitation frequency and distribution in the country. The authors observed a persistent negative trend (since the end of 19th century) in the number of wet days across Italy, ranging from $-7 \%$ per century to $-15 \%$ per century, with the greatest contributions to yearly trends originating from spring and autumn. An increasing positive significant trend in precipitation intensity in the northern regions of the country was also observed. The authors attributed the increase in precipitation intensity to a decrease in the contribution of low precipitation categories to total precipitation and to an increase in that of higher categories corresponding to heavy precipitation events. Clearly, the studies reported in $[10,16,17]$ relate to the 20th century hydrometeorology research on Australia, UK and Italy respectively. The hydrometeorology of sub-Saharan Africa has been demonstrated by numerous studies [18-22]. In [19], Conway et al., used river basin rainfall series and extensive river flow records from nine major international river basins to characterize spatial and temporal variability in sub-Saharan African water resources over the period 1931-1990. The authors observed a substantial variability in rainfall and river flows between 1931-1960 and 1961-1990 in West Africa. On decadal time scales, sub-Saharan Africa was reported to exhibit drying across the Sahel after the early 1970s, relative stability disrupted by extreme wet years in East Africa, and periodic behavior underlying high inter-annual variability in Southern Africa.

The increased attention to extreme weather and climate events raises numerous worldwide questions. For example, it is unclear whether these extreme events are truly increasing, society as a whole has become more vulnerable to extreme weather [23] or it is only a perceived increase aggravated by enhanced media coverage, or some combination [15]. The biggest obstacle that limits assessment of weather and climate events and quantifying whether these events have changed over the 20th century either globally or on regional scales is the lack of long-term hydro-met data [24]. In particular, a number of countries suffer from poor distribution of hydro-met observation networks (in terms of both density and coverage).

The goal of the present review is two-fold. Firstly, the hydro-met research landscape in South Africa is not exhaustive in spite of important scientific and socio-economic applications. Rather, various hydro-met research activities are embedded in established research niches like climatology, meteorology, agrometeorology, and hydrology. In this contribution, we review a number of research initiatives that directly or indirectly fall under hydrometeorology. Through such a review, we hope to illustrate the scope and current baseline research in hydrometeorology in South Africa. Secondly, hydro-met data and products are not readily available in pre-processed and uniform formats. For example, the available hydromet data sets are often in raw format and in various file formats. While we understand that various institutions like the Water Research Commission (WRC), Council for Scientific 
and Industrial Research (CSIR), Department of Water Affairs (DWA), University of Kwa-Zulu Natal (UKZN) and South African Weather Service (SAWS) continue to provide some hydro-met products, these products are provided in various file formats and archived in databases that are not sufficiently accessible to the scientific community. This review attempts to investigate the current hydro-met research landscape and assesses various factors that influence hydro-met research in South Africa. As a result, the present review contributes to understanding the state of hydro-met research activities and overall initiatives in South Africa.

\section{Spatial Extend of Hydrometeorology in South Africa}

Hydrological processes of a given region are often understood through studying river basins. For instance, observed hydro-met variables in selected river basins may be used to evaluate the ability of models to characterize hydrological processes that are linked to extreme weather events such as drought and floods [25]. South Africa contains 22 major rivers, 165 large dams, more than 4000 medium and small dams on public and private land, and hundreds of small rivers [26]. The four largest river basins in South Africa in descending order are Orange, Limpopo, Komati and Olifants. Table 1 details some of the characteristics of these river basins.

The four river basins are international river systems as they are shared among different southern African countries. They cross and form borders between riparian countries, simultaneously acting as the largest water resources in countries and regions classified as semi-arid and subjected to increasing water stress. These shared-water basins hold tremendous potential for various natural resources, including cross-boundary hydropower production, larger scale multi-country irrigation schemes, inter- and intra-country navigation, joint inland fishering development, joint water supply sources utilization, environmental protection, wild life conservation, recreation and eco-tourism development, etc. [27]. River basins are often characterized by their tributaries (small rivers flowing into a larger river), watershed (an area of highland surrounding the river basin), confluence (where a river joins another river), source (the start of a river) and mouth (where a river meets the sea or an ocean). Most of these rivers and their surrounding catchment areas are equipped with hydrometric gauges and water level sensors used to monitor runoff, water quality and other parameters that are useful in conservation of water resources. The DWA maintains an up-to-date online database of runoff information for monitoring hydrometric gauge stations found within South Africa [26]. The department continuously collects water samples and analyses to assess the quality of the water resource and its suitability for use [28].

Table 1. Physical description of the most common river basins in South Africa. Source: [29].

\begin{tabular}{cccccccc}
\hline $\begin{array}{c}\text { River } \\
\text { Basin }\end{array}$ & $\begin{array}{c}\text { No. of Riparian } \\
\text { Countries }\end{array}$ & $\begin{array}{c}\text { Total } \\
\text { Catchment } \\
\text { Area }\left(\mathbf{k m}^{\mathbf{2}}\right)\end{array}$ & $\begin{array}{c}\text { Catchment } \\
\text { Area in } \\
\text { SA } \mathbf{( \mathbf { k m } ^ { 2 } )}\end{array}$ & $\begin{array}{c}\text { Basin Area } \\
\mathbf{\%}\end{array}$ & $\begin{array}{c}\text { No. of Dams } \\
\text { in SA }\end{array}$ & $\begin{array}{c}\text { Mean Annual } \\
\text { Rainfall Volume } \\
\left(\mathbf{1 0}^{\mathbf{6}} \mathbf{~ m}^{\mathbf{3}}\right)\end{array}$ & $\begin{array}{c}\text { Storage Capacity } \\
\mathbf{1 0}^{\mathbf{6}}\left(\mathbf{m}^{\mathbf{3}}\right)\end{array}$ \\
\hline Orange & 4 & 964,000 & 563,900 & 25.4 & 24 & 11,200 & 12 \\
Limpopo & 4 & 414,800 & 183,500 & 45 & 26 & 5,750 & 12 \\
Olifants & 2 & 54,570 & & & 9 & 2,400 & \\
Komati & 3 & 50,000 & 29,200 & 62.5 & 22 & 3,600 & \\
\hline
\end{tabular}




\section{Hydrometeorological Services and Products}

\subsection{Hydrometeorological Services in South Africa}

According to the World Meteorological Organization (WMO), hydro-met activities play an essential role in the safety and welfare of humanity. The WMO is an intergovernmental organization established in 1950 and currently composed of 191 member countries and territories. South Africa is one of the member states of the WMO and receives support and guidance from the agency in activities related to hydrology and water resources problems in the context of socio-economic development and environmental protection. The main emphasis is on international exchange of experience and technology, the international dissemination of hydrological information, forecasts and warnings, and raising public awareness of the socio-economic and environmental significance of water. In line with WMO requirements and guidelines, SAWS has been running hydro-met activities since the mid 1990s, supported by various WRC-funded projects. The most current hydro-met projects conducted by SAWS include: (1) implementation of a hydro-met modelling system (South African Flash Flood Guidance (SAFFG)) to model potential flash floods based on satellite or radar rainfall estimates, soil moisture and runoff modelling; (2) development of a seasonal river flow forecasting system for South Africa; (3) development and implementation of a radar- and satellite-based Quantitative Precipitation Estimation (QPE) system to approximate the amount of precipitation that has fallen at a given location or across a specific region; (4) support for the DWA Flood Room through a dedicated flow of relevant information and forecasts necessary for flood warning activities and the River Forecasting System in the Vaal-Orange river system, operated by DWA.

Almost all of these projects are funded by the WRC of South Africa, an organization committed to promoting a better quality of life for all through funding fundamental water research, growing scientific capacity and disseminating knowledge to various important stakeholders. Its funded projects directly address the country's water challenges by investigating new technologies and methods to enhance water and sanitation supply, supporting policy and legislation and providing much-needed guidance to implementers. The South African WRC funds research projects covering, for instance, all aspects of the hydrologic cycle, including water resource management, aquatic ecosystems, water use and waste management, the use of water in agriculture, and issues like climate change that may affect the country's water resources in the future. The WRC works hand-in-hand with the DWA in formulating provincial strategic plans to support service delivery for various hydrological activities (e.g., weather and climate) through the Directorate of Hydrology. This Directorate is, among other things, responsible for the operation of a Flood Room, which in turn is responsible for issuing flood warnings in the Orange-Vaal River systems as well as management of the Vaal Dam and other dams in this system. The DWA provides various products and services, e.g., daily flows, dam level and rainfall information; weekly state of dams; river flow modelling for river floods; river flood warning; provincial rainfall trends; flood management; water resources management; and many others.

The CSIR, through their Water and Human Health Groups, contributes to dealing with challenges in the water sector through a variety of research that focuses on the assessment and management of water resources to ensure an optimum supply of quality water to the users while ensuring the integrity of the resource base. In particular, the CSIR research groups focus on, among other things, quantification and characterization of groundwater to supply sustainable development; assessment of aquatic ecosystem 
processes, management, and protection; and usage of the National Water Resource Classification System to classify water resources and to facilitate a balance between protection and use of the nation's water resources. The UKZN has also been involved in leading water-related and hydro-met research in South Africa. Their home groomed model (Agricultural Catchment Research Unit or ACRU) has been used and verified on data from South Africa, Swaziland, Zimbabwe, Germany and the United State of America (USA) [30,31], Canada [32,33] and New Zealand [34,35]. The ACRU model has since been used for agrometeorogical and hydro-met forecasting purposes as well as for impact assessment studies (e.g., runoff modelling), as in [36,37]. The UKZN research group and their collaborative partners have undertaken various case studies using the ACRU model as an Installed Hydrological Modelling System (IHMS) on numerous river catchments across KZN and nearby provinces. Examples of such studies include: (1) Indicators of hydrological alteration for assessing environmental flows for highly variable rivers; (2) Planning for the environmental reserve of the Mkomazi catchment and (3) Meso-scale indicators of water poverty in the Thukela catchment, South Africa, under baseline land cover conditions. For detailed information on these case studies, the reader is referred to [38] and references therein. Examples of other institutions (research \& academic) indirectly contributing towards hydrometeorology services include the Agricultural Research Council (Institute for Soil, Water and Climate), University of Pretoria (Department of Geography, Geoinformatics and Meteorology), Rhodes University (Department of Environmental Science), University of Free State (Faculty of Natural and Agricultural Sciences), University of Cape Town (Department of Environmental and Geographical Science).

It is important to note that hydrometeorology research in South Africa is in its infancy, yet there are a plethora of studies linked to hydrometeorology that have existed for a number of decades. These studies were conducted by small research groups that existed within established disciplines. The studies have contributed to hydrometeorology services in South Africa nonetheless. Additionally, the role of the private sector (i.e., through private research initiatives from companies) cannot be ignored. In particular, the public and private partnership geared towards tackling adverse effects of climate change is one of the key areas where hydrometeorology services could be attained.

\subsection{Products and Applications}

There are various hydro-met products that can be derived from a typical hydrometeorology station. Precipitation (amount and duration) describes the water that falls to the earth surface from the atmosphere in either liquid or solid form. Thus precipitation includes rainfall in liquid form or snow, sleet, and hail in solid form. Precipitation data are the most important data used in hydro-met analysis as precipitation forms the foundation for runoff generated in catchments and sub-catchments. Evapotranspiration of surface water from seas, oceans, rivers, lakes, dams, catchments, etc. as well as from plants, vegetation and trees are other important variables or products derived from hydro-met observations. In particular, evaporation is one of the primary inputs to catchment rainfall runoff models and is hence also used to determine water losses from wetlands, reservoirs, and aquifers and the water requirements of crops under irrigation. Other products derived from hydro-met observations include temperature, atmospheric pressure, humidity, solar radiation, stream flow, water levels (surface and groundwater), wind speed and direction, horizontal visibility, soil moisture content, lightning, vegetation cover, etc. 
Data derived from hydro-met observations form the basis for knowledge, decision making and actions in fields such as water management, agriculture, energy, aviation, transport, risk management, etc. Water resources planning and management is currently a challenge to the South African community. South Africa is facing scarcity of water resources, the most challenging of constraints known to influence economic growth, social justice and ecological integrity in various developed and still developing countries. Approximately $40 \%$ of the world's population in over 80 countries experience water scarcity [39]. In addition, rapid growth in population, urbanization, agricultural activities, industrial development and natural occurrences (drought) have also contributed to the increased demand for water resources in various parts of the world, leaving water resources planners to continually look for additional sources of water to supplement the limited resources available to their regions.

The Department of Water Affairs and Forestry (DWAF) in South Africa has developed a National Water Resource Strategy (NWRS) to address the management of water resources to meet the development goals of the country [40]. The NWRS is tasked, among other objectives, with identifying areas of the country with limited water resources and constrained development, as well as development opportunities where water resources are available. Three possible issues have been identified as the main factors affecting South African water resources management. Firstly, the national conditions and low rainfall with high evaporation rates create low availability of runoff. The second main factor leading to greater water demand and possible scarcity of water resources involves population growth, economic development and pollution. Thirdly, the policies related to management of water resources often determine the procedure used by relevant authorities when managing resources and directly impacts other driving forces and pressures.

In South Africa, regions situated in the south-eastern coast receive high rainfall while the western and interior regions of the country are arid and semi-arid. The quality and quantity of water change as a result of seasonal and intra-annual rainfall changes, particularly in rivers [41]. Thus the availability of water is limited during the dry season due to South African river flow being low for much of the year, with periodic high flows. Climate change, a natural cycle whereby climate changes to accommodate the energy received from the sun, has been reported to exhibit a huge impact on water resources [42-46]. One of the most important impacts of climate change as reported in the literature is on hydrology, which results in changes in river flows and regional water resources [47], making it difficult to estimate river runoff. Climate change is expected to reinforce the global hydrological cycle, leading to an increase in many impacts on regional water resources. It has also been projected that climate will have prominent effects on the available runoff. For instance, a change in the total amount, frequency and intensity of precipitation will directly affect the amount and timing of runoff and intensity of floods and droughts [48]. Climate change is also believed to increase water stresses by decreasing runoff in areas such as Southern Africa, whilst runoff decreases in other parts of the world [49]. In particular, due to climate change related to reductions in the frequency of rainy days [50] and a later onset of the rainy season during spring [51], South Africa is expected to become wetter in the east and drier in the west, particularly during the December-February period [52].

\section{Review of Hydrometeorology Research Studies in South Africa}

Numerous studies on applications of hydrometeorology observations dating back almost four decades have been presented by various researchers and research groups in the literature. For example, using 
available rainfall data for all recording stations in Kruger National Park, [53] compiled a rainfall map for the region and investigated the cyclic nature of the annual rainfall as well as the rainfall distribution within the cycles. The author found that the rainfall statistic for Kruger National Park confirmed the recurrent cyclic nature reported earlier by [54]. Annual rainfall totals and intra- and inter-annual rainfall variability trends from 1970 to 2000 were analyzed by [55], using rainfall records from 13 stations along a latitudinal and altitudinal gradient in the KwaZulu-Natal Drakensberg foothills east of the escarpment. In these studies, the authors detected a significant spatial trend in annual rainfall variability with a mean annual rainfall in the Drakensberg attributed to altitude, distance and the location to the eastern side of the Drakensberg escarpment. Furthermore, rainfall in the KwaZulu-Natal Drakensberg foothills was reported to display intra- and inter- annual variability not necessarily influenced by altitude or the relation to the escarpment.

In [12], Mason et al., investigated changes in extreme rainfall events in South Africa using rainfall data from 314 stations across the country for the period 1931-1990. In this study, significant increases in the intensity of the extreme rainfall events between 1931-1960 and 1961-1990 were identified over about $70 \%$ of the country. In addition, the intensity of the 10 -year high rainfall events was found to have increased by $10 \%$ over large areas of the country except in parts of the northwest as well as in the winter rainfall region of the southwest. In [56], Roy and Rouault used hourly precipitation data from 1998 to 2007 across 102 stations in South Africa to analyze trends in extreme hourly precipitation events. Results included predominantly positive trends during summer, with the strongest trends concentrated in the coastal areas in the southeast. Reversed spatial variations in the trends during the winter season were also reported, with observed negative trends in the coastal areas and positive trends in the interior.

In [57], Reason et al., investigated inter-annual variability of dry spells frequencies, dry and wet spell characteristics and onset dates of the austral summer rainy season over the Limpopo region of northern South Africa. Results included that summer dry spell frequency and onset were related to ENSO via changes in regional circulation. In particular it was reported that Niño 3.4 sea surface temperature anomalies appeared to exhibit a relationship with dry spell frequency during the analyzed period of 1972-2002. In addition, anomalies in onset date of the rainy season during 1979-2002 were found to be inversely related to Niño 3.4 sea surface temperature, with the relationship strengthening after 1986. Studies by [58] used precipitation data from 11 South African regions to investigate periodicities, ENSO effects and trends in rainfall series for the period 1900-1998. The author found that 8 regions had maximum precipitation in the austral summer months whilst the remaining 3 had the maximum in autumn and winter. In addition, annual values were reported to exhibit significant year-to-year fluctuations (e.g., $50 \%$ to $200 \%$ of the mean) while five-year running means depicted long-term fluctuations ( $75 \%$ to $150 \%$ of the mean). The relationship between El Niño Southern Oscillation (ENSO) and South Africa austral winter rainfall was analyzed in [59] by Philippon et al., using a 662-rain-gauge daily rainfall database documenting the period 1950-1999. The findings were that the May, June and July seasonal amount depicted a positive correlation with the El Niño 3.4 index that became significant since the 1976/1977 climate regime shift.

In [60], Dollar and Rowntree investigated hydro-climatic trends, sediment sources and geomorphic response in the Bell River catchment in the Eastern Cape Drakensburg of South Africa. In this study no evidence for progressive long term change in the rainfall pattern for the catchment was detected, but annual and seasonal rainfall cycles with variance peaks occurring every 16-19 years were reported. 
Based on these results the authors suggested that flood events following years of below average rainfall may cross the threshold limit for channel stability, which is often followed by a major flood event after sustained low rainfall periods. In [61], Grenfell and Ellery investigated the impact of stream-flow on sediment transport and geomorphology of the Mfolozi River in South Africa and found that sediment transport variability occurred at the intra- and inter-annual scale. Further analysis of mean monthly sediment concentration and discharge were found to show a hysteresis effect, suggesting that sediment concentration peaked prior to discharge in the early wet season. Low sediment concentrations were reported on the peak discharges during the late wet season.

\section{Key Challenges of Hydrometeorology Research and Recommendations}

This contribution takes into account the fact that hydrometeorology research focus groups exist across the world, suggesting that this research field indeed plays an important role in the wellbeing of humankind. In addition, most hydrometeorology studies reported in the literature are done in Europe, the US, China and other internationally involved countries, focusing all the impacts of weather and climate events in their regions. In particular, most of these countries have implemented several programs and activities that deal with the study of hydrometeorology of extreme events and mitigation of their effects. In addition, many of these countries (e.g., USA, Australia, Canada, England, India, Russia, Scotland, etc.) have established an operational hydro-met capacity to assist with forecasting and warning, as well as informing the public of possible heavy rain, floods, droughts, etc. In contrast, hydrometeorology research in Africa (in general) and South Africa (in particular) is still in its infancy. There are a number of compounding factors that contribute to this state of affairs. Firstly, there is currently a big gap in Africa in terms of spatial distribution of stations involved with hydro-met observations. Most of the stations are spread out and clumped in the Northern and Southern Africa. As a result, Africa has a very irregular network of hydro-met stations needed for comprehensive hydrometeorology research.

In South Africa most of the sites either have no hydro-met data sets or the sites have collected incomplete data or only selected a few variables of interest. Even if there are weather stations run by private organizations or farmers, there is no guarantee that the gathered data are shared with the public regionally or nationally. This obviously creates data gaps at multiple levels and limits hydrometeorology research activities in the country. This review associated the research gaps with various factors, including, among others, poor distribution of the hydro-met observation network, limited access to hydro-met data and products, and inadequate research groups and institutions conducting hydro-met research. Additionally, the hydrometeorology research support base (financially) is limited. In line with these limitations the following is therefore suggested: an advanced method to fill in network gaps by expanding hydro-met observations network; advanced methods of filling data gaps by using ground observations, reanalysis data and satellite data; establishing or upgrading the database management system for easy access to hydro-met data in an appropriate format; and increasing partnerships and collaborations between national and international research and academic institutions in various hydrometeorology activities to promote sharing of knowledge and experience. In addition, it is important to access historical weather and climate data, as it can be used to efficiently manage water resources. 


\section{Conclusions}

Accurate prediction of hydro-climate extremes is vital to society, as it contributes to timely preparation for and mitigation of disasters. Human and economic losses that often result from natural (weather and climate related) disasters such as storms, heat/cold fronts, floods and droughts could be reduced if governments (and regional) organizations were capable of providing comprehensive hydrometeorological services at appropriate lead times. A robust and functional hydrometeorological system is therefore critical for disaster risk mitigation, preparedness and response. This review attempts to unravel the status quo of hydrometeorology research in South Africa. While research fields such as hydrology, climatology and meteorology have received considerable interest (albeit from few research institutions), hydrometeorology research remains non-exhaustive. This conclusion is based on (a) a critical analysis of hydrometeorological services and products and (b) a review of the actual hydrometeorology research activities. Both perspectives point towards the lack of a functional hydrometeorological system. A robust hydrometeorological system ought to exhibit two main tenets: (a) established best practice hydro-met and weather hazard monitoring and early warning system, which can be established through advanced application of hydro-met technologies and data; (b) succinctly strengthened hydrometeorological services and products through investments. Without a clear hydrometeorological system, we are compelled to conclude that hydrometeorology is still in its infancy. While this statement might seem far-fetched to many colleagues who have been involved in hydrometeorology research in South Africa dating as far back as 1970s, the reality is that at present, progress in this interdisciplinary research field is dormant. The authors take this extreme view for a number of reasons. Firstly, South Africa has a very poor network of hydro-met stations i.e., gauged stations dedicated to hydrometeorology research. The existing stations either have numerous data gaps or unsuitable temporal resolution of data records. Second, there are very few hydrometeorology experts in South Africa. We say this due to the small number of institutions that actively participate in hydrometeorology research. Further, the number of hydrometeorology publications from scientists based in South Africa is very low. A survey of the literature corroborates this fact. There is clearly a lack of active research activities which cover the whole spectrum of hydrometeorology research i.e., observations, modelling and prediction. Only one institution (i.e., UKZN) has been actively involved in this field of research. Third, there is no single program at academic universities that is dedicated to hydrometeorology. Instead, many of the hydrometeorology activities are implied and embedded in traditional study programs. In conclusion, provision of decision support information on weather, climate and water resources allows society to be prepared for and responsive to hydrometeorological threats. In the context of South Africa, such a decision support system (i.e., the hydrometeorological system) should be envisioned by all stakeholders, including governments and private organizations. The hydrometeorological system should be able to provide effective hydrometeorological data and services that meet the needs of the general public, emergency services and other specialized users. The hydrometeorological system ought to have the following salient characteristics:

(a) An effective hydrometeorological extreme events warning service network and database in order to provide appropriate and timely services and products;

(b) Strengthened institutional capacity development; 
(c) Cooperation among national, regional and international organizations in order to carry out research related to hydrometeorology and water resources.

\section{Acknowledgments}

The authors wish to thank the anonymous reviewers for their constructive and detailed comments that helped to improve the quality of the manuscript.

\section{Author Contributions}

All authors were involved in conceptualizing, designing and discussing the study. Christina Botai drafted and finalized the manuscript. Joel Botai coordinated the group study and edited the manuscript. Shepherd Muchuru drafted specific sections of the manuscript. Isaac Ngwana edited the manuscript. All the authors have read and approved the final manuscript.

\section{Conflicts of Interest}

The authors declare no conflict of interest.

\section{References}

1. Mora, D.E.; Campozano, L.; Cisneros, F.; Wyseure, G.; Willems, P. Climate changes of hydrometeorological and hydrological extremes in the Paute basin, Ecuadorean Andes. Hydrol. Earth Syst. Sci. 2004, 18, 631-648.

2. Domenico, P.A.; Schwartz, F.W. Physical and Chemical Hydrogeology; John Wiley and Sons, Inc.: New York, NY, USA, 1990.

3. Sophocleous, M. Interactions between groundwater and surface water: The state of the science. Hydrol. J. 2002, 10, 52-67.

4. Alley, W.A.; Healy, R.W.; LaBaugh, J.W.; Reilly, T.E. Flow and storage in groundwater systems. Science 2002, 296, 1985-1990.

5. Kuchment, L.S. The hydrological cycle and human impact on it. In Water Resource Management; Eolss Publisher: Oxford, UK, 2004.

6. Valverde, A.L.A. Understanding the hydrological cycle: Key to sustainable development. WMO Bull. 2008, 57, 169-172.

7. Kinter, J.L.; Shuka, J. The global hydrologic and energy cycles: Suggestions for studies in the pre-global energy and water cycle experiment (GEWEX) period. Bull. Am. Meteorol. Soc. 1990, 71, 181-189.

8. Rogers, D.; Tsirkunov, V. Implementing Hazard Early Warning Systems; Global Facility for Disaster Reduction and Recovery: Washington, DC, USA, 2011.

9. Coates, L. An overview of fatalities from some natural hazards in Australia. In Proceedings of the NDR96 Conference on Natural Disaster Reduction, Institute of Engineers Australia, Canberra, Australia, 29 September-2 October 1996; pp. 49-54.

10. Suppiah, R.; Hennessy, K.J. Trends in the total rainfall, heavy rain events and number of dry days in Australia, 1910-1990. Int. J. Climatol. 1998, 10, 1141-1164. 
11. IPCC. Managing the risks of extreme events and disasters to advance climate change adaptation. In A Special Report of Working Groups I and II of the Intergovernmental Panel on Climate Change; Field, C.B., Barros, V., Stocker, T.F., Qin, D., Dokken, D.J., Ebi, K.L., Mastrandrea, M.D., Mach, K.J., Plattner, G.-K., Allen, S.K., et al., Eds.; Cambridge University Press: Cambridge, UK; New York, NY, USA, 2012; p. 582.

12. Mason, S.J.; Waylen, P.R.; Mimmack, G.M.; Rajaratnam, B.; Harrison, J.M. Changes in external rainfall events in South Africa. Clim. Chang. 1999, 41, 249-257.

13. Chahine, M.T. The hydrological cycle and its influence on climate. Nature 1992, 359, 373-379.

14. Frei, C.; Schar, C.; Luthi, D.; Davies, H.C. Heavy precipitation processes in a warmer climate. Geophys. Res. Lett. 1998, 25, 1431-1434.

15. Karl, T.R.; Easterling, D.R. Climate extremes: Selected review and future research directions. Clim. Chang. 1999, 42, 309-325.

16. Osborn, T.J.; Hulme, M.; Jones, P.D.; Basnett, T.A. Observed trends in the daily intensity of United Kingdom precipitation. Int. J. Climatol. 2000, 20, 347-364.

17. Brunetti, M.; Maugeri, M.; Monti, F.; Nanni, T. Changes in daily precipitation frequency and distribution in Italy over the last 120 years. J. Geophys. Res. 2004, 109, 1-16.

18. Sene, K.J.; Plinston, D.T. A review and update of the hydrology of Lake Victoria in East Africa. Hydrol. Sci. J. 1994, 39, 47-63.

19. Conway, D.; Persechino, A.; Ardoin-Bardin, S.; Hamandawana, H.; Dieulin, C.; Mahe, G. Rainfall and water resources variability in sub-Saharan Africa during the twentieth century. J. Hydrometeor. 2009, 10, 41-59.

20. Khan, S.I.; Adhikari, P.; Hong, Y.; Vergara, H.; Adler, R.F.; Policelli, F.; Irwin, D.; Korme, T.; Okello, L. Hydroclimatology of Lake Victoria region using hydrologic model and satellite remote sensing data. Hydrol. Earth Syst. Sci. 2011, 15, 107-117.

21. Okoli, C. The hydrometeorology of Niger River Basin. Adv. Mater. Res. 2013, 824, 613-629.

22. Nyeko-Ogiramoi, P.; Willems, P.; Gaddi-Ngirane, K. Trend and variability in observed hydrometeorological extremes in the Lake Victoria Basin. J. Hydrol. 2013, 489, 56-73.

23. Kunkel, K.; Pielke, R.A., Jr.; Changnon, S.A. Temporal fluctuations in weather and climate extremes that cause economic and human health impacts: A review. Bull. Am. Meteor. Soc. 1999, 80, 1077-1098.

24. Easterling, D.R.; Diaz, H.F.; Douglas, A.V.; Hogg, W.D.; Kunkel, K.E.; Rogers, J.C.; Wilkinson, J.F. Long-term observations for monitoring extremes in the Americas. Clim. Chang. 1999, 42, 285-308.

25. Van Lanen, H.A.J.; Tallaksen, L.; Candel, M.J.J.M.; Carrera, J.; Crooks, S.M.; Engeland, K.; Fendeková, M.; Haddeland, I.; Hisdal, H.; Horacek, S.; et al. Database with Hydrometeorological Variables for Selected River Basins: Metadata Catalogue; WATCH Technical Report 4; Wageningen University: Wageningen, The Netherlands, 2008. Available online: http://www. eu-watch.org/publications/technical-reports (accessed on 25 November 2014).

26. Water Affairs. South Africa Yearbook 2013/2014. Available online: http://www.southafrica-newyork.net/ consulate/Yearbook_2014/2013-4Water_Affairs.pdf (accessed on 20 March 2015).

27. United Nations Economic Commission for Africa (UNECA). Transboundary River/Lake Basin Water Development in Africa: Prospects, Problems and Achievements; UNECA: Addis Ababa, Ethiopia, 2000.

28. Department of Water Affairs and Forestry (DWAF). Republic of South Africa; Annual Report, 1 April 2008 to 31 March 2009; DWAF: Pretoria, South Africa, 2009. 
29. African Ministers Council On Water; African Network of Basin Organizations. Source Book on Africa's River and Lake Basin Organisations; AMCOW: Abuja, Nigeria; ANBO: Dakar, Senegal, 2007; Volume 1, pp. 1-88.

30. Schulze, R.E. Hydrology and Agrohydrology: A Text to Accompany the ACRU 3.00 Agrohydrological Modelling System; WRC Report No. TT 69/95; Water Research Commission: Pretoria, South Africa, 1995; p. 552.

31. Schulze, R.E.; Pike, A. Development and Evaluation of an Installed Hydrological Modelling System; WRC Report No. 1155/1/04; Water Research Commission: Pretoria, South Africa, 2004; p. 179.

32. Kienzle, S.W.; Schmidt, J. Hydrological impacts of irrigated agriculture in the Manuherikia Catchment Otago, New Zealand. J. Hydrol. N. Zeal. 2008, 47, 67-84.

33. Schmidt, J.; Kienzle, S.W.; Srinivasan, M.S. Estimating increased evapotranspiration losses caused by irrigated agriculture as part of the water balance of the Orari Catchment, Canterbury, New Zealand. J. Hydrol. N. Zeal. 2009, 48, 73-94.

34. Kienzle, S.W. Effects of area under-estimations of sloped mountain terrain on simulated hydrological behaviour: A case study using the ACRU model. Hydrol. Proc. 2011, 25, 1212-1227.

35. Kienzle, S.W.; Nemeth, M.W.; Byrne, J.M.; MacDonald, R.J. Simulating the hydrological impacts of climate change in the Upper North Saskatchewan River Basin, Alberta, Canada. J. Hydrol. 2012, 412-413, 76-89.

36. Smithers, J.C.; Schulze, R.E.; Pike, A.; Jewitt, G.P.W. A hydrological perspective of the February 2000 floods: A case study in the Sabie River Catchment. Water S. Afr. 2001, 27, 325-332.

37. Smithers, J.C.; Chetty, K.T.; Frezghi, M.S.; Knoesen, D.M.; Tewolde, M.H. Development and assessment of a daily time-step continuous simulation modelling approach for design flood estimation at ungauged locations: ACRU model and Thukela Catchment case study. Water S. Afr. 2013, 39, 1-16.

38. Schulze, R.E.; Smithers, J.C. The ACRU modelling system as of 2001: Background, concepts, structure, output, typical applications and operations. In Modelling as a Tool in Integrated Water Resources Management: Conceptual Issues and Case Study Applications; WRC Report 749/1/02; Schulze, R.E., Ed.; Water Research Commission: Pretoria, South Africa, 2002; Chapter 2, pp. 47-84.

39. Wallace, J.S. Increasing agricultural water use efficiency to meet future food production. Agric. Ecosyst. Environ. 2000, 82, 105-119.

40. DWAF. National Water Resource Strategy, 1st ed.; DWAF: Pretoria, South Africa, 2004.

41. Mukheibir, P.; Sparks, D. Water Resource Management and Climate Change in South Africa: Visions, Driving Factors and Sustainable Development Indicators; Energy \& Development Research Centre, University of Cape Town: Cape Town, South Africa, 2003.

42. Calder, I.R.; Hall, R.L.; Bastable, H.G.; Gunston, H.M.; Shela, O.; Chirwa, A.; Kafundu, R. The impact of land use change on water resources in sub-Saharan Africa: A modelling study of Lake Malawi. J. Hydrol. 1995, 170, 123-135.

43. Middelkoop, H.; Daamen, K.; Gellens, D.; Grabs, W.; Kwadijk, J.C.J.; Lang, H.; Parmet, B.W.A.H.; Schädler, B.; Schulla, J.; Wilke, K. Impact of Climate Change on Hydrological Regimes and Water Resources Management in the Rhine Basin. Clim. Chang. 2001, 49, 105-128.

44. Jiang, T.; Chen, Y.D.; Xu, C.-Y.; Chen, X. Comparison of hydrological impacts of climate change simulated by six hydrological models in the Dongjiang Basin, South China. J. Hydrol. 2007, 336, $316-333$. 
45. Hay, L.F.; McCabe, G.J. Hydrologic effects of climate change in the Yukon River Basin. Clim. Chang. 2010, 200, 509-523.

46. Taye, M.T.; Ntegeka, V.; Ogiramoi, N.P.; Willems, P. Assessment of climate change impact on hydrological extremes in two source regions of the Nile River Basin. Hydrol. Earth Syst. 2011, 15, 209-222.

47. Hassan, R. Impact of Climate Change on Crop Production in Burkina Faso; Policy Note No. 24; Publisher: Cape Town, South Africa, 2006.

48. Mukheibir, P. Local water resource management strategies for adaptation to climate induced impacts in South Africa. In Proceedings of the Workshop on Rural Development and the Role of Food, Water and Biomass: Opportunities for Development and Climate, Dakar, Senegal, 14-16 November 2005.

49. Arnell, N.W. Climate change and global water resources: SRES emissions and socio-economic scenarios. Glob. Environ. Chang. 2004, 14, 31-52.

50. Tadross, M.; Suarez, P.; Lotsch, A.; Hachigonta, S.; Mdoka, M.; Unganai, L.; Kamdonyo, D.; Muchinda, M.; Lucio, F. Changes in daily rainfall characteristics affecting agriculture: Observations and projections for Malawi, Mozambique and Zambia. In Institutions for Climate Change Adaptation; World Bank: Washington, DC, USA, 2007; p. 32.

51. Tadross, M.A.; Hewitson, B.C.; Usman, M.T. The interannual variability of the onset of the maize growing season over South Africa and Zimbabwe. J. Clim. 2005, 18, 3356-3372.

52. Hewitson, B.C.; Crane, R.G. Consensus between GCM climate change projections with empirical downscaling: Precipitation downscaling over South Africa. Int. J. Climatol. 2006, 26, 1315-1337.

53. Gertenbach, W.P.D. Rainfall patterns in the Kruger National Park. Koedoe 1980, 23, 35-43.

54. Tyson, P.D.; Dyer, T.G.J. The predicted above-normal rainfall of the Seventies and the likelihood of droughts in the eighties in South Africa. S. Afr. J. Sci. 1978, 74, 372-377.

55. Nel, W.; Sumner, P.D. Trends in rainfall total and variability (1970-2000) along the KwaZulu-Natal Drakensberg foothills. S. Afr. Geogr. J. 2006, 88, 130-137.

56. Roy, S.S.; Rouault, M. Spatial patterns of seasonal scale trends in extreme hourly precipitation in South Africa. Appl. Geogr. 2013, 39, 151-157.

57. Reason, C.J.C.; Hachigonta, S.; Phaladi, R.F. Interannual variability in rainy season characteristics over the Limpopo region of Southern Africa. Int. J. Climatol. 2005, 25, 1835-1853.

58. Kane, R.P. Periodicities, ENSO effects and trends of some South African rainfall series: An update. S. Afr. J. Sci. 2009, 105, 199-207.

59. Philippon, N.; Rouault, M.; Richard, Y.; Favre, A. The influence of ENSO on winter rainfall in South Africa. Int. J. Climatol. 2012, 32, 2333-2347.

60. Dollar, R.S.J.; Rowntree, K.M. Hydroclimatic trends, sediment sources and geomorphic response in the Bell River catchment, Eastern Cape Drakensberg, South Africa. S. Afr. Geogr. J. 1995, 77, 21-32.

61. Grenfell, S.E.; Ellery, W.N. Hydrology, sediment transport dynamics and geomorphology of a variable flow river: The Mfolozi River, South Africa. Water SA 2009, 35, 271-282.

(C) 2015 by the authors; licensee MDPI, Basel, Switzerland. This article is an open access article distributed under the terms and conditions of the Creative Commons Attribution license (http://creativecommons.org/licenses/by/4.0/). 